\title{
PERBEDAAN INDIVIDU: RAGAM GAYA BELAJAR DAN KIAT SUKSES DALAM PEMBELAJARAN BAHASA ARAB
}

\author{
Imelda Wahyuni \\ Institut Agama Islam Negeri Kendari \\ imelda@iainkendari.ac.id
}

\begin{abstract}
Abstrak
Artikel ini bertujuan untuk mendeskripsikan perbedaan individu dan kiat sukses dalam pembelajaran bahasa Arab. Penelitian lapangan menggunakan pendekatan kualitatif ini merupakan studi kasus pembelajaran bahasa Arab pada Mata Kuliah Bahasa Arab 1 dan Bahasa Arab 2 di Fakultas Tarbiyah dan Ilmu Keguruan IAIN Kendari. Teknik pengumpulan data yang digunakan adalah wawancara, observasi, dan studi dokumentasi. Analisis data dilakukan melalui reduksi, penyajian, dan verifikasi data, sedangkan uji keabsahan data dilakukan dengan teknik triangulasi. Hasil penelitian menunjukkan beberapa temuan, yaitu: pertama; perbedaan individu dalam pembelajaran bahasa Arab pada Fakultas Tarbiyah dan Ilmu Keguruan terjadi pada gaya belajar mahasiswa, baik gaya belajar introvert maupun gaya belajar extrovert. Gaya belajar introvert dan extrovert terdeteksi melalui rangkaian aktivitas belajar mahasiswa baik pada jadwal perkuliahan maupun di luar jadwal perkuliahan. Kedua, kiat sukses mahasiswa dalam pembelajaran bahasa Arab ditunjukkan melalui beberapa cara alami, yaitu: memahami kekurangan pengetahuan dasar bahasa Arab, berinteraksi aktif dalam kegiatan belajar bahasa Arab secara maksimal, melaksanakan latihan komunikasi (lisan dan tulisan) secara bermakna dan memotivasi diri secara mandiri. Perbedaan individu melalui gaya belajar mahasiswa dalam pembelajaran Bahasa Arab di Fakultas Tarbiyah memberi dampak positif pada konstruksi kiat sukses belajar Bahasa Arab bagi mahasiswa.
\end{abstract}

Katakuci: Perbedaan Individu, Gaya Belajar, Kiat Sukses dan Pembelajaran Bahasa Arab.

\begin{abstract}
This article aims to describe individual differences and tips for success in Arabic learning. This field research used a qualitative approach in a case study of Arabic learning in Bahasa Arab 1 and Bahasa Arab 2 Courses at the Faculty of Teacher Training and Education at IAIN Kendari. The data collection techniques used were interviews, observation, and documentation studies. Data analysis was carried out through data reduction, presentation, and verification, while the data validity test was carried out using triangulation techniques. The results showed several findings, namely: first; individual differences in Arabic learning at the Faculty of Teacher Training and Education occur in students' learning styles, both introverted and extroverted learning
\end{abstract}


styles. Introvert and extrovert learning styles are detected through a series of student learning activities both on the lecture schedule and outside the lecture schedule. Second, students' success tips in Arabic learning are shown in several natural ways, namely: understanding the lack of Arabic basic knowledge, interacting actively in Arabic learning activities to the fullest, carrying out communication exercises (oral and written) meaningfully and motivating themselves independently. Individual differences through student learning styles in Arabic learning at the Faculty of Teacher Training and Education have a positive impact on the construction of successful tips for Arabic learning students.

Keywords: Individual Difference, Learning Styles, Successful ips and Arabic learning.

\section{Pendahuluan}

Kontinuitas pelaksanaan pendidikan berjenjang menjadi syarat ketercapaian tujuan pendidikan bagi bangsa Indonesia. Lembaga pendidikan tinggi menjadi jenjang akhir setelah melewati jenjang pra pendidikan, pendidikan dasar dan pendidikan menengah. Salah satu varian lembaga pendidikan tinggi di Indonesia adalah Perguruan Tinggi Keagamaan Islam (selanjutnya disebut PTKI), lembaga pendidikan ini adalah representasi tempat belajar dan mengembangkan pengetahuan bahasa Asing, khususnya bahasa Arab dan Bahasa Inggris. Pembelajaran bahasa Asing dapat efektif jika upaya peningkatan penguasaan bahasa Arab dipahami sebagai kebutuhan urgen (Crystal, 2010), (Brick, 2006). Bahasa Arab menjadi populer seiring berkembangnya bentuk pendidikan di Indonesia, khususnya di pondok pesantren (Perdana, 2017). Pembelajaran bahasa Arab di universitas dimulai dengan menyiapkan kemampuan kompetensi dan pengetahuan metodologi (Arsyad, 2009). Arsyad menegaskan beberapa metode efektif dalam pembelajaran bahasa Arab yang diadopsi dari pengalaman praktis ahli di Barat (Arsyad \& Majid, 2010). Pandangan para ahli tersebut menegaskan posisi vital pembelajaran bahasa Asing pada jenjang pendidikan tinggi, secara khusus penguasaan bahasa Arab dapat dikonfirmasi kepada kebutuhan dan tujuan belajar setiap pebelajar.

PTKI di Indonesia pada umumnya menyelenggarakan pembelajaran Bahasa Arab sebagai bagian dari kurikulum yang berlaku atau pelaksanaan pembelajaran tersebut berdasarkan keberadaan program studi Pendidikan Bahasa Arab atau Program Studi Bahasa dan Sastra Arab. Kedua alasan diselenggarakannya pembelajaran Bahasa Arab tersebut memiliki target capaian yang berbeda pada tataran pelaksanaan kurikulum maka pembelajaran Bahasa Arab berlangsung pada PTKI umumnya sebagai mata kuliah 
institusi dan dilaksnakan pada seluruh program studi pada lembaga PTKI tersebut. Sedangkan sebagai kebutuhan inti program studi khusus seperti Program Studi Pendidikan Bahasa Arab maka rangkaian pembelajaran bahasa Arab mengacuh pada kurikulum program studi tersebut.

Pelaksanaan pembelajaran bahasa Arab di PTKI berbasis kurikulum pendidikan nasional yang menegaskan daftar varian ilmu pengetahuan dan kompetensi yang ditargetkan. Kajian menarik terkait eksistensi proses pembelajaran bahasa Arab menjadi penting untuk diperbincangkan, setiap individu yang terlibat dalam kegiatan pembelajaran memiliki kesamaan sekaligus perbedaan. Penulis beranggapan bahwa keterlibatan seorang tenaga pengajar (selanjutnya disebut dosen) pada suatu pembelajaran harus meluangkan waktu untuk mengamati dan memperhatikan kondisi perbedaan fisik dan psikis setiap individu yang diajar, seperti; minat, bakat, kemampuan, motivasi, pembawaan, karakter, kecenderungan, kebiasaan dan performa pebelajar. Selain itu, perbedaan non fisik yang terkait dengan kemampuan (intelengensi), karakter, bakat, gaya belajar, motivasi, identitas dan afiliasi kelompok etnis peserta didik (Lightbown, n.d.). Namun, artikel ini hanya fokus pada deskripsi gaya belajar bahasa Arab mahasiswa pada PTKI.

Stigma peserta didik tentang pembelajaran bahasa Arab yang telah ditemukan oleh peneliti sebelumnya bahwa banyak peserta didik yang merasa sulit bahkan menganggap pembelajaran bahasa Arab itu sangat susah dipahami (Ihsan, 2017). Temuan pada penelitian lain adalah terdapat $22 \%$ responden menganggap muatan materi bahasa Arab terlalu padat dan susah dimengerti (Kosim et al., 2020). Hal tersebut seharusnya menjadi fakta yang dikonfirmasi melalui kajian terkait perbedaan individu dalam menanggapi stigma tersebut agar tidak menjadi momok dalam pembelajaran bahsa Arab. Penelitian terkait masalah pembelajaran Bahasa Arab di madrasah menguak bahwa ragam masalah dalam pembelajaran bahasa Arab adalah perbedaan wawasan, banyaknya pengalaman, minat dan motivasi dalam pembelajaran Bahasa Arab (Hizbullah \& Mardiah, 2015). Berbagai temuan terkait kajian ini berasal dari rangkaian pembelajaran Bahasa Arab pada jenjang pendidikan menengah, sedangkan kajian ini dapat menyajikan informasi yang menegaskan bahwa perbedaan individu akan dapat menjadi unsur yang dapat menunjukan betapa perbedaan individu dapat membedakan 
stigma awal masing-masing individu dalam belajar bahasa Arab sehingga menjadi lebih bervariasi pada jenjang pendidikan tinggi.

Meskipun penelitian sebelumnya menemukan bahwa perbedan individu dapat dilihat pada perbedaan gaya belajar peserta didik dan kecenderungan keterampilan berbahasa pada bahasa asing atau bahkan bahasa Ibu peserta didik tersebut. Namun kajian ini hadir untuk mencari fakta bagaimana perbedaan individu (mahasiswa) memberi warna dan dinamika dalam tataran gaya belajar yang lebih mengulas gaya introvert dan ekstrovert dalam pembelajaran bahasa Arab. Oleh karena itu, kajian ini lebih fokus mengkaji spesifikasi pada gaya yang cenderung ditunjukkan oleh peserta didik dalam belajar secara formal dalam kelas sesuai jadwal pembelajarn dan gaya yang dilakukan ketika berada pada momen belajar di saat di luar jadwal pembelajaran. Kajian perbedaan individu ini fokus pada pembelajaran Bahasa Arab di pendidikan tinggi, khususnya pada Fakultas Tarbiyah dan Ilmu Keguruan (FTIK) IAIN Kendari.

Pembelajaran Bahasa Arab di FTIK Kendari yang terdistribusi pada 10 Program Studi terdiri dari Mata kuliah Bahasa Arab I dan Bahasa Arab II. Mata kuliah ini termasuk dalam mata kuliah institusi yang didistribusi pada seluruh program studi pada setiap fakultas di IAIN Kendari. Namun, Program Studi Pendidikan Bahasa Arab mendistribusikan mata kuliah yang seluruhnya sesuai dengan kebutuhan prodi tersebut. Penulis menegaskan bahwa artikel ini fokus pada pembelajaran mata kuliah Bahasa Arab I dan Bahasa Arab II saja. Penelitian sebelumnya menemukan bahwa pembelajaran mata kuliah Bahasa Arab di FTIK IAIN Kendari telah mengalami perubahan setelah peninjauan kurikulum, sehingga sebelumnya mata kuliah ini didistribusi lebih banyak tahap, yaitu bahasa Arab I hingga Bahasa Arab IV. Temuan ini memberi kontribusi terhadap pembelajaran bahasa Arab yang megalami reduksi jumlah tahapan namun tidak mereduksi frekuensi pembelajaran bahasa Arab secara formal karena tetap diperuntukkan bagi semester awal pada setiap angkatan. Materi mengalami penggabungan akibat distribusinya dialokasikan hanya pada 2 (dua) tahap untuk dua semester berbeda. Namun artikel ini hanya akan fokus pada dua keterempilan produktif, yaitu keterampilan berbicara dan keterampilan menulis. Perbedaan tersebut menjadi faktor pembeda antara satu individu dan individu lainnya, sehingga berimplikasi terhadap tingkah laku belajar dan hasil belajar mereka. 


\section{Metode Penelitian}

Perbedaan individu dalam belajar bahasa Arab yang ditunjukkan oleh mahasiswa Fakultas Tarbiyah dan Ilmu Keguruan IAIN Kendari dikaji melalui penelitian studi kasus. Perbedaan yang ditunjukkan oleh mahasiswa menjadi data yang dikumpulkan melalui teknik wawancara dan observasi selama pembelajaran bahasa Arab I dan Bahasa Arab II. Perbedaan yang ditunjukan dapat menunjukkan kecenderungan aktivitas belajar yang dilakukan oleh mahasiswa. Sedangkan perbedaan tersebut diamati melalui gaya belajar para mahasiswa dalam mengetahui dan menguasai keterampilan bahasa Arab. Sehingga teknik analisis yang digunakan adalah analisis kualitatif (Bryman, A., \& Burgess, 2002) dan disertai dengan pengecekan keabsahan data melalui triangulasi.

\section{Konsep Perbedaan Individu}

Upaya memahami konsep perbedaan individu diawali dengan mengetahui dan memahami makna "individu", baik secara bahasa maupun secara istilah. Individu secara bahasa adalah orang seorang; pribadi orang (terpisah dari orang lain). Selain itu dapat pula diartikan sebagai organisme yang hidupnya berdiri sendiri, secara fisiologi bersifat bebas (tidak memiliki hubungan organik dengan sesamanya). Sumber lain menyebutkan bahwa asal kata individu adalah"individera" atau "individum" berarti satu kesatuan organisme yang tidak dapat terbagidan tidak dapat dipisahkan. Manusia merupakan makhluk individu yang menjadi bagian dari seluruh segmen kajian dalam kehidupan manusia, seperti dalam pemaknaan manusia sebagai mahluk yang berpikir (homo sapiens), mahluk sebagai pekerja (homo faber), mahluk yang dapat dididik (homo educandum). Manusia sebagai makhluk yang dapat dididik menjadi individu yang memiliki keunikan atau karakteristik yang berbeda antara satu dan yang lainnya.

Seorang manusia terlahir sebagai makhluk individu yang tumbuh dan berkembang melalui fase tertentu. Pada masa awal kelahiran manusia sebagai makhluk individu belum terlihat karakter pada dirinya, tetapi kebutuhannya dominan masih pada kebutuhan fisik. Manusia sebagai makhluk individu segera mengenal lingkungan pada masa perkembangan selanjutnya maka pada saat itulah manusia menyandang status makhluk individu dan makhluk sosial. Secara istilah individu dapat diartikan sebagai 
seseorang yang memiliki peranan dalam lingkungan sosial atau memiliki kepribadian serta pola tingkah laku yang spesifik tentang dirinya sendiri. Oleh karena itu, makna lain terkait istilah individu adalah unit terkecil pembentuk masyarakat. Individu dapat dipahami sebagai bagian terkecil dan terpisah-pisah dalam suatu komunitas terkecil, seperti dalam komunitas pembelajaran maka individu adalah setiap orang (mahasiswa) dari seluruh jumlah individu yang berada dalam suatu kelompok belajar tersebut.

Perbedaan individu adalah sebuah bagian penting yang diperbincangkan dalam diskusi dari masa ke masa dalam kehidupan manusia. Perbedaan tersebut dapat dipahami berdasarkan ruang lingkup pengkajian tertentu, apabila perbedaan individu diperbincangkan dalam kajian terkait perkembangan atau pertumbungan individu maka kajian tersebut mengarah pada pembahasan perubahan fisik dan psikis setiap individu dalam melewati fase perkembangan dan pertumbuhan. Namun, apabila perbincangan tentang perbedaan individu dihubungkan dengan kegiatan pembelajaran maka kajian tersebut terarah pada pembicaraan tentang perbedaan setiap individu dari segi kecakapan, kemampuan, bakat, minat, motivasi, dan kesiapan untuk terlibat dalam kegiatan pembelajaran tersebut.

Sejauh ini perbedaan individu dipahami dengan mengetahui karakteristik seseorang sebagai individu yang memiliki kecenderungan dan ditetapkan sebagai ciriciri yang khas pada setiap individu secara utuh. Ciri-ciri yang khas tersebut membedakan seorang individu dengan individu yang lainnya. Karakteristik (Rachman, 2017) seseorang dapat diketahui dengan memahami klasifikasi antara karakter seseorang yang terdapat atau dimiliki sejak lahir atau biasa disebut dengan karakter bawaan dan karakter yang dimiliki seseorang setelah mendapat pengaruh lingkungan. Klasifikasi ini menegaskan bahwa karakter bawaan seseorang merupakan karakter turunan yang dapat dilihat dari sisi biologis dan sisi sosial, karakter terkait biologis cenderung statis sedangkan karakter terkait sosial cenderung mengalami perubahan sesuai pengaruh lingkungan sekitarnya.

Istilah lain terkait kedua karakter pada paragraph sebelumnya diungkapkan oleh Ichsan bahwa kedua karakter tersebut dikenal sebagai faktor penyebab adanya perbedaan individu, yakni faktor warisan sejak lahir dan faktor perkembangan dan pengalaman berbasis pengaruh lingkungan. Terjadi konvergensi antara kedua faktor 
tersebut, sehingga terlihat seorang individu yang lebih dominan faktor keturunannya dibandingkan individu lain yang lebih dominan faktor lingkungannya. Secara alamiah kedua faktor tersebut dapat berinteraksi sesuai dengan kecenderungan masing-masing individu (Ichsan, 2009).

Kedua klasifikasi karakter tersebut telah menjadi bagian pada sosok individu, keberadaannya sebagai makhluk pribadi maupun sebagai makhluk sosial terbaca melalui karakter yang dimiliki dan berlaku pada lingkungan pribadi maupun sosial mereka. Individu adalah gambaran perseorangan yang tetap menjadi bagian dari kelompok sosial, perbedaan antara setiap individu menjadi bagian dalam pembelajaran bahasa. Setiap individu menunjukkan perbedaan tersebut dalam merespon kegiatan belajar bahasa, individu yang sejak lahir telah membawa kecakapan berbahasa yang baik dan pada masa perkembangannya mendapat pengaruh dari lingkungan yang mendukung kecakapan berbahasanya. Interaksi kedua hal tersebut membuat kecakapan individu dapat berkembang dengan baik karena kecakapan berbahasa didukung oleh lingkungan yang menguatkan posisi individu dalam mengekplorasi keterampilan berbahasa. Lingkungan sosial tempat berkembangnya kecakapan tersebut dapat menimbulkan pengaruh satu sama lain.

\section{Ragam Perbedaan Individu}

Perbedaan individu dapat dideteksi dan diamati dengan memahami beberapa faktor yang mempengaruhi setiap perbedaan yang terdapat dalam diri seseorang. Perbedaan ini dapat diklasifikasi berdasarkan dua faktor, yaitu faktor umum dan faktor personal (Ellis, 1989). Faktor personal meliputi perbedaan yang bersifat internal dan sangat mendekati ranah psikologis, seperti sikap seorang peserta didik terhadap tenaga pengajar dan respon peserta didik tersebut terhadap materi bahasa Arab yang diajarkan. Terkadang ditemukan ketidaksesuaian antara tingkah laku dan mimik atau ekspresi seorang peserta didik yang kurang respek terhadap gaya mengajar seorang tenaga pengajar sehingga mempengaruhi kenyaman dalam belajar. Atau contoh lain, pada dinamika kelompok, apabila individu dapat memandang kompetititornya dengan positif maka individu tersebut selalu merasa ingin berkompetisi, dan perbedaan berikutnya adalah teknik belajar individual ynag diwarnai dengan kebiasaan belajar dan sangat beragam yang pada akhirnya terhegemoni dengan kecenderungan tertentu. 
Sedangkan faktor umum meliputi hal-hal yang bersifat umum seperti: perbedaan usia berdasarkan kelayakan tingkatan usia pembelajaran. Pembelajaran selalu mempertimbangkan faktor usia yang dihubungkan dengan pemilihan materi, penggunaan media, dan penerapan metode. Bagian lain dari faktor umum tersebut adalah kecerdasan dan ketangkasan (kecakapan), cara berpikir (cognitive-style), motivasi dan kepribadian. Adapun uraian masing-masing perbedaan individu berdasarkan faktor tersebut dapat diuraikan ragam perbedaan individu sebagai berikut:

Pertama, faktor usia merupakan salah satu faktor umum perbedaan individu, jenjang pendidikan ditetapkan berbasis usia, hal ini dikarenakan faktor usia dapat mempengaruhi pencapaian tujuan belajar. Terkait dengan pembelajaran bahasa asing, beberapa ahli mengungkap bahwa usia dan siklus bertambahnya sangat memungkinkan untuk dianalisa tingkat kebutuhan pendidikan anak. Anak usia 0-5 tahun tidak membutuhkan pengasahan keterampilan akademik seperti yang dianjurkan bagi para orang dewasa. Starting time bagi peserta didik ditinjau dari segi usia juga selalu mengundang kontroversi di kalangan tenaga ahli pendidik karena dengan pergeseran zaman maka terdapat materi yang sudah mengalami pergeseran. Sebagaimana pendapat bahwa masa kanak-kanak adalah masa yang tepat karena terdapat periode kritis (critical period). Periode kritis adalah masa ketika otak dapat mencerna bahasa dengan baik. Terkait dengan hal tersebut, beberapa penelitian (Hurd, 2006) menemukan bahwa pelafalan dan kemampuan menyimpan memori anak-anak lebih baik sedangkan orang dewasa yang memiliki kematangan kognitif lebih baik jika memahami sifat bahasa yang abstrak tanpa menggunakan prase yang rumit.

Kedua, faktor kecerdasan dan ketangkasan, setiap individu mempunyai kecakapan tertentu, namun kecakapan tersebut tidak mutlak hadir dalam diri seseorang berdasarkan faktor genetik atau keturunan. Kecakapan dapat dimiliki seseorang melalui pengalaman dan perkembangan, sehingga kecakapan dapat dikenali dalam dua bentuk klasifikasi, yaitu kecakapan dasar (potensial ability) dan kecakapan nyata (actual ability). Kecakapan dasar dapat ditunjukkan dari kecakapan yang terkandung dalam diri individu dan diperoleh secara herediter, kecakapan tersebut dapat berupa abilitar dasar umum dan abilitar dasar khusus dalam bidang tertentu (bakat khusus, sikap). fSedangkan kecakapan nyata adalah aspek yang dapat langsung ditunjukkan dan diuji 
karena hasil usaha atau cara belajar individu tersebut telah dijalani melalui proses pembelajaran (achievement, prestasi).

Kecakapan potensial hanya dapat dideteksi dengan mengidentifikasi indikatorindikator prilaku intelegen. Adapun indikator tersebut dipopulerkan oleh Witherington dalam beberapa istilah, yaitu: facility in uses of numbers, language efficiency, speed of perception, facility of memorizing, facility in comprehending relationships, and imagination. Istilah ini dikenal dalam bahasa Indonesia dengan indikator sebagai berikut: kemudahan dalam menggunakan bilangan, efisiensi dalam berbahasa, kecepatan dalam pengamatan, kemudahan dalam mengingat, kemudahan dalam memahami hubungan, dan imajinasi (Amin Syamsuddin Makmun, 1999).

Sedangkan kecakapan menurut Gardner (Gardner, 1993) dikenal dengan kecakapan majemuk (multipleintellegence). Terdapat delapan kecakapan berdasarkan pendapat Garnerd tersebut, yaitu: linguistic Intelegence (word smart), logical marthmaical intellegence (reasoning smart), Visual spatial intelligence (picture smart), Bodily kinesthetic intelligence (body smart), Musical intelligence (music smart), Interpersonal intelligence (people smart), Intrapersonal intelligence (self smart), Naturalist intelligence (nature smart). Perbedaan kecerdasan pada setiap individu memiliki indikator umum, seseorang dapat dikatakan cerdas berdasarkan tes IQ yang terstruktur dan dapat dipengaruhi oleh faktor genetik. Istilah ini juga disebutkan dalam istilah yang berbeda, yaitu kecakapan. Kecakapan sudah tentu mempengaruhi proses pembelajaran, khusunya kemampuan memahami tiga domain pembelajaran, yaitu kognitif, afektif, dan psikomotorik. Meskipun demikian kecerdasan tidak sepenuhnya penentu utama dalam keberhasilan belajar, khusunya belajar bahasa.

Hal ini relevan dengan hasil penelitian yang dilakukan Genesee (lightbown, n.d.), menemukan bahawa kecerdasan terkait dengan membaca, tata bahasa, dan kosakata namun kecerdasan tidak terkait dengan kemampuan produktif bahasa. Jadi kecerdasan memiliki hubungan yang sangat kuat dengan pengetahuan metalinguistik dibandingkan dengan kemampuan untuk berkomunikasi. Selain itu, kecerdasan yang berbeda dapat menghasilkan output yang berbeda. Howard Gardner merumuskan delapan jenis kecerdasan, salah satu di antaranya adalah kecerdasan bahasa. Rumusan ini populer hingga kini dengan istilah multiple intelligences. Kecerdasan multipel 
meliputi kecerdasan bahasa, kecerdasan logika, kecerdasan visual-spasial, kecerdasan musik, kecerdasan gerak, kecerdasan alam, kecerdasan sosial dan kecerdasan diri (Gardner, 1993).

Ketangkasan adalah kemampuan khusus yang dimiliki seseorang, ketangkasan dapat meringkas waktu dan mereview tempat dalam kehidupan, ketangkasan membuat seseorang dapat melakukan sesuatu dengan relatif singkat dan praktis serta hemat waktu. Pendapat ahli lain menyebutkan bahwa kesuksesan belajar dapat dipengaruhi oleh ketangkasan (Zafar \& Meenakshi, 2012). Ketangkasan atau kecakapan memiliki kontribusi terhadap pembelajaran bahasa berdasarkan beberapa indikator yang telah dijelaskan sebelumnya.

Ketiga, cara berfikir adalah cara seseorang memaknai, menyusun, mengorganisasi dan mengingat informasi. Cara berfikir dikenal dengan istilah cognitive-style yang dimaknai oleh seorang ahli merupakan susunan dan tata caracara berfikir seseorang (Cook, 2008) dan (Ellis, 1989). Cara berfikir ini tentu mengambil peran yang sangat strategis dalam pembelajaran, apabila seseorang menyimak kata/kalimat maka mahasiswa tersebut mulai memaknai, menyusun, mengorganiir, dan mengingat kata dan kalimat. Apabila proses berfikir tidak fokus maka informasi yang diterima dapat diorganisir dalam keadaan tidak sempurna. Ada dua jenis cara berfikir yaitu field dependence dan field independence. Berfikir dengan pola field dependence lebih mudah dipengaruhi oleh lingkungan maka terkadang seseorang berbeda dengan individu lainnya namun pada akhirnya mengikut pada komunitas mayoritas akibat pengaruh lingkungan tersebut. Adapun berfikir berdasarkan field independence adalah sebaliknya, seseorang mampu bertahan dan tidak mudah terpropokasi atau terpengaruhi.(Ellis, 1989)

Cara berfikir dapat diklasifikasi dalam 4 bentuk, yaitu: Pertama, concrete learning style, cara ini memproses informasi secara aktif dan langsung, proses berfikir lebih difokuskan pada sesuatu yang konkrit dan berdasarkan pengalaman. Kedua, Analytical learning style, cara berfikir secara sistematis dan logis, cara berfikir seperti ini cenderung menyelesaikan masalah dan sangat prinsipil. Ketiga, Communicative learning style, berfikir dengan menekankan pendekatan sosial atau masyarakat. Kempat, Authority-oriented learning style berfikir dengan memperhatikan tanggung jawab. 
Keempat, motivasi dapat dianalisa dari pendapat beberapa ahli. Motivasi berasal dari kata "motif" yang berarti daya upaya yang mendorong seseorang untuk melakukan sesuatu. Motif dapat maknai dengan daya penggerak yang berasal dari dalam maupun luar diri seseorang untuk melakukan aktivitas-aktivitas tertentu untuk memperoleh suatu target. Apabila dirubah menjadi kata "motivasi" maka mengandung makna seduah daya penggerak yang menggerakkan seseorang untuk melakukan suatu perbuatan dan berdasarkan rumusan tujuan tertentu. Gerakan yang ditimbulkan sangat dipengaruhi oleh kebutuhan yang ingin dipenuhi (http://kbbi. web. id, 2016).

Motivasi menjadi salah satu faktor yang terdapat dalam perbedaan individu. Setiap individu memiliki dorongan belajar yang berbeda berdasarkan kecenderungan dan latar belakang masing-masing individu. Motivasi merupakan salah satu faktor yang penting dalam pembelajaran bahasa. Individu yang sangat termotivasi menetapkan standar yang tinggi bagi dirinya dan tidak mudah goyah, sekali memilih jalan pantang untung menyimpang atau membelok, bekerja keras untuk memperoleh segala yang diinginkan, dan tetap menyelesaikan tugas meskipun menghadapi hambatan. Sebaliknya, individu yang kurang motivasi mudah menyerah menjalani sesuatu yang dirasakan sulit karena dalam menghadapi tantangan besar merka mudah menyerah (Crozier, 2013).

Motivasi terbagi menjadi dua, yaitu integrative dan instrumental. Integrative motivation adalah motivasi yang muncul dari diri pebelajar karena ketertarikannya dengan bahasa yang dipelajarinya dan keinginanya untuk menjadi bagian dari komunitas atau budaya bahasa tersebut. Instrumental motivation adalah motivasi yang muncul karena pemelajar ingin mendapatkan keuntungan dari bahasa yang dipelajari seperti mendapatkan kerja, lulus dalam tes dan lain sebagainya.

Kelima, kepribadian dalam konsepsi psikologi belum ditemukan kesepahaman terkait definisi "kepribadian", sehingga beberapa ahli mencoba merumuskannya dalam istilah sebagai berikut, Allport menyebutkannya sebagai sebuah organisasi dinamis dalam sistem psikis dan fisik individu yang menentukan karakteristik perilaku dan pikiran seseorang. Sedangkan menurut Pervin dan John dimaknai sebagai kepribadian mewakili karakteristik individu yang terdiri dari pola-pola pikiran, perasaan dan perilaku yang konsisten. Definisi lain diungkapkan oleh Adler, bahwa kepribadian 
adalah gaya hidup individu atau cara yang khas dari individu tersebut dalam memnerikan respon terhadap masalah-masalah hidup. Chaplin mengungkapkan pula kepribadian adalah integrasi dari sifat-sifat tertentu yang dapat diselidiki dan dijabarkan untuk menyatakan kualitas unik dari individu.

Kepribadian manusia menurut Renee Baron dan Elizabeth Wagele (Baron, Renee dan Wagele, 2015) dapat dilihat dalam Sembilan tipe, pertama; perfeksionis, tipe ini termotivasi dengan kebutuhan untuk hidup dengan benar, memperbaiki diri sendiri dan orang lain, dan menghindari amarah. Kedua; penolong, tipe ini dimotivasi oleh kebutuhan untuk dicintai dan dihargai, mengekspresi perasaan positif pada orang lain dan menghindari kesan membutuhkan. Ketiga; mengejar prestasi, tipe ini termotivasi oleh kebutuhan untuk menjadi orang yang produktif dalam meraih kesuksesan dan terhindar dari kegagalan. Keempat; romantis, tipe ini termotivasi oleh kebutuhan untuk memahami perasaan diri sendiri serta dipahami orang lain, menemukan makna hidup dan menghindari citra diri. Kelima; pengamat, tipe ini termotivasi oleh kebutuhan untuk mengetahui segala sesuatu dan alam semesta, merasa cukup dengan diri sendiri dan menjaga jarak, serta menghindari kesan bodoh atau tidak memiliki jawaban. Keenam; pencemas, tipe ini termotivasi oleh kebutuhan untuk mendapatkan persetujuan, merasa diperhatikan, dan terhidar dari kesan pemberontak. Ketujuh; peluang, tipe ini termotivasi oleh kebutuhan untuk merasa bahagia serta merencanakan hal-hal menyenangkan, member sumbangsih kepada dunia dan terhindar dari derita duka cita. Kedelapan; pejuang, tipe ini termotivasi oleh kebutuhan untuk mengandalkan diri sendiri, member pengaruh dari dunia, dan terhindar dari kesan lemah. Kesembilan; kepribadian setiap individu berbeda-beda dan mempengaruhi segala tingkah lakunya, baik yang alamiah maupun yng terstruktur.

Keperibadian menuntun seorang individu untuk bertindak dan mengambil keputusan pada setiap peristiwa yang terkait dengan keberadaannya. Keperibadian menjadi atribut performance bagi setiap individu, misalnya upaya untuk mengenal seseorang maka dilakukan dengan jalan mengingat sesuatu yang terbiasa dilakukan dan bahkan repleks, sehingga karakteristik dapat dihubungkan dengan beberapa tingkah laku dominan atau yang sering dilakukan seseorang. Perbedaan yang ditunjukkan melalui sikap dan tingkah laku tersebut merupakan bagian dari perbedaan individu. 


\section{Perbedaan Gaya Belajar Mahasiswa dalam Pembelajaran Bahasa Arab}

Perbedaan gaya belajar mahasiswa pada Fakultas Tarbiyah dan Ilmu Keguruan IAIN Kendari teramati melalui aktivitas belajar Bahasa Arab pada kelas perkuliahan Bahasa Arab 1 dan Bahasa Arab 2, baik pada semester ganjil maupun semester genap. Terdapat beberapa mahasiswa yang cenderung memaksimalkan kompetensi berpikir dan berindak sebagai bagian dari kegiatan belajar pada ruang perkulianan. Kecenderungan gaya belajar mahasiswa teramati melalui cara dan gaya berpikir mahasiswa dalam rangkaian kegiatan pembelajaran. Berikut beberapa ragam gaya yang ditunjukkan mahasiswa: Pertama, terdapat mahasiswa menunjukkan respon dan tanggapan melalui tindakan belajar yang repleks disampaikan secara langsung, misalnya terjadi pada saat dosen menyampaikan materi Bahasa Arab, secara spontan salah satu mahasiswa (alumni pondok pesantren) repleks menanggapi materi tersebut sesuai dengan pengalaman belajar semasa di pondok dan langsung menyebutkan secara konkrit dalam bentuk contoh lisan dan tulis. Gaya belajar melalui metode berpikir seperti ini juga ditunjukkan oleh mahasiswa lain yang kerapkali hanya memberi penegasan terhadap poin materi yang disampaikan oleh dosen, respon yang ditunjukkan sebagai gaya belajar beru tanggapan teoretis yang sangat erat kaitannya dengan unsur structural pembelajaran Bahasa Arab atau identik dengan istilah "Qawaid". Gaya belajar ini terlihat sangat responsif dan terkonfirmasi oleh dosen yang menyatakan bahwa pada umumnya mahasiswa alumni pondok pesantren lebih responsive dalam menanggapi aktvitas belajar. Terlihat pula pada dokumen Lembar Latihan mahasiswa yang menunjukkan ragam gaya dalam menunjukkan kompetensi pada rangkaian aktivitas belajar.

Kedua, terdapat mahasiswa menunjukkan gaya belajar melalui respon cara berpikir yang sangat kritis dan prinsipil. Hal ini ditemukan pada situasi pembelajaran materi Bahasa Arab pada penguasaan keterampilan berbicara, momen pada saat dosen memberikan contoh tertulis tentang materi yang diajarkan, terlihat seorang mahasiswa yang menyampaikan kritik struktural terkait tata Bahasa Arab pada contoh tertulis dengan mengungkapkan prinsip pemahaman yang diadopsi dari hasil bacaan referensi. Mahasiswa tersebut menghalau rasa kaku yang terlihat pada mahasiswa lainnya dengan secara lugas menyampaikan kritik konstruktif terhadap contoh tertulis materi tersebut. Gaya belajar secara aktif dan kritis ditunjukkan melalui sikap antusias dalam menyampaikan kritik lisan dan tulisan terhadap materi pembelajaran. 
Ketiga, terdapat mahasiswa yang menunjukkan gaya belajar melalui cara berpikir dan merespon aktivitas belajar dengan beradaptasi pada kondisi kelas pembelajaran. Mahasiswa mengekspresikan keterampilan berbicara melalui kecakapan menggunakan beberapa kosa kata Bahasa Arab secara terstruktur dan sistematis. Mahasiswa alumni sekolah menengah atas, baik dari Madrasah Aliyah maupun dari Sekolah Menengah Umum terpengaruh oleh gaya komunikasi mahasiswa alumni pondok pesantren yang mendemonstrasikan kemampuan berbicara sesuai bekal dasar kemampuan berbahasa Arab yang dimiliki sejak belajar di pondok pesantren. Komunitas heterogeny mahasiswa menciptakan kondisi kebersamaan dalam situasi belajar yang menunjukkan kecenderungan cara berpikir yang mengikuti sikap dan perilaku mahasiswa yang dominan menunjukkan kemampuan lebih mapan dalam berbicara menggunakan Bahasa Arab.

Gaya belajar dan kecenderungan cara berpikir mahasiswa tersebut memberi berdampak pada gaya belajar mahasiswa FTIK pada situasi belajar di luar kelas pembelajaran. Mahasiswa terlihat melewati momen belajar secara berkelompok dan terjadi secara alami seiring dengan sistuasi aktivitas sosial dan interaksi sesame mahasiswa, bahkan antar mahasiswa yang bukan se kelas. Hal ini ditegaskan pula oleh dosen bahwa tugas kelompok yang dirancang dan diinstruksi sebagai bagian dari aktivitas belajar merupakan upaya untuk memediasi kegiatan belajar bersama mahasiswa untuk tujuan lebih kompleks, yaitu saling berbagi pengetahuan berbahasa Arab. Selain, belajar secara berkelompok, mahasiswa FTIK terlihat menunjukkan gaya belajar individu yang lebih identik dengan gaya personal setiap mahasiswa. Mahasiswa menuturkan bahwa lebih mudah menerima kekurangan keterbatasan ketika mereka menemukan batas pengetahuannya secara mandiri. Misalnya, mahasiswa dalam menyelesaikan tugas individu terlihat lebih konsentrasi pada titik point yang tidak dapat diselesaikan dengan baik. Hal ini terlihat pula pada lembar tugas Latihan, terdapat beberapa nomor tugas Latihan yang dikosongkan dan terkonfirmasi kepada mahasiswa yang bersangkutan bahwa soal tersebut tidak dipahami dengan baik dan mahasiswa tersebut memilih untuk tidak menyelesikannya.

Penelitian terkait perbedaan individu oleh Nelson menemukan bahwa anak berusia 1-2 tahun pada umumnya menguasai 50 (lima puluh) kata, namun ditemukan bahwa pada setiap anak penguasaan katanya berbeda-beda, baik yang berupa kata 
ataupun frase. Sebahagian mereka belajar bahasa dalam bentuk gaya referensial, sebahagian besar kata yang mereka peroleh adalah kata-kata benda serta sebahagian kecil adalah kata sifat dan kata kerja. Selain itu penelitian ini juga menmukan bahaw terdapat beberapa anak yang belajar bahasa dalam bentuk gaya ekspresif. Berbeda dengan anak yang menggunakan gaya referensial, anak yang jumlahnya relatif lebih sedikit dari yanggunakan gaya referensial ini lebih dominan menggunakan kata ganti kata benda dan kondisi-kondisi sosial.

Kemampuan dan ketersediaan waktu dosen dalam mengamati perbedaan gaya belajar mahasiswa tersebut harus berkesesuaian dengan kondisi obyektif mahasiswa sebagai unsur atau pelaku belajar bahasa. Pada jenjang pendidkan menengah, temuan Zagoto dan kawan-kawan pada penelitiannya menyebutkan bahwa pendidik memiliki kemampuan dan memahami berbagai macam strategi untuk mengetahui perbedaan individu dalam kelas pembelajaran yang dilaksanakan, baik sebagai bagian dari pengamatan personal maupun sebagai bagian pengamatan kolektif dalam kelas pembelajaran bahkan pengajar harus dapat memahami kompetensi interpersonal yang mengalami peningkatan pada diri masing-masing peserta didik (Zagoto et al., 2019).

Gaya belajar yang tercermin dari cara berpikir dan menetukan sikap, respon dan prilaku dalam aktivitas belajar mahasa Arab bagi mahasiswa FTIK pada mata kuliah Bahasa Arab 1 dan Bahasa Arab 2 ini teramati berbasis momen belajar di ruang kelas sesuai jadwal perkuliahan dan pada kondisi belajar di luar kelas dan jadwal kelas memiliki sinergitas pada bentuk gaya belajar yang identic dengan gaya introvert dan gaya ekstrovert. Mahasiswa yang menunjukkan sikap introvert lebih merasa fleksibel dengan gaya belajar secara individu, sedangkan bagi mahasiswa yang memiliki kecenderungan gaya ekstrovert lebih produktif dalam belajar berkelompok dan terbuka untuk berdiskusi dan berbagai informasi kepada mahasiswa yang lain. menjadi objek yang menarik untuk dihubungkan dengan kiat mahasiswa dalam sukses belajar Bahasa Arab.

\section{Kiat Mahasiswa Sukses Belajar Bahasa Arab}

Mahasiswa memiliki kiat masing-masing untuk sukses dalam belajar Bahasa Arab. Berdasarkan hasil pengamatan selama situasi belajar dan proses evaluasi dosen disebutkan bahwa variasi ketercapaian tujuan belajar mahasiswa menunjukkan 
perbedaan keterampilan yang dikuasai oleh setiap mahasiswa. Hal ini menunjukkan bahwa kegiatan belajar Bahasa Arab terlaksana sesaui dengan rancangan tertentu, secara khusus tips sukses dalam belajar Bahasa Arab dimanfaatkan dengan berbagai upaya, yaitu; pertama, mahasiswa memahami hal signifikan yang menjadi modal awal belajar Bahasa Arab. Bekal awal yang dimiliki mahasiswa memiliki keterbatasan sehingga penguasaan kompetensi mahasiswa sangan tergantung pada kemampuan dasar berbahasa Arab yang dimilikinya. Penuturan salah seorang mahasisw yang telah merefleksi penguasaan keterampilan berbahasa Arab pada sistuasi belajar di kelas maupun di luar kelas menyatakan bahwa lebih mudah menemukan kebutuhan belajar jika memahami keterbatasn yang dimililki. Tips unik yang dilakukan oleh mahasiswa tersebut adalah menunjukkan keterbatasan yang dimilikinya secara sportif tanpa rasa kikuk, baik pada kegiatan Latihan materi ajar maupun pada situasi belajar alami pada waktu luang di luar jadwal kuliah.

Kedua, tips yang juga diterapkan mahasiswa adalah berupaya untuk menjajaki kesesuaian antara kemampuan dasar mereka dengan materi yang disampaikan pada kelas perkuliahan. Terlihat kiat mahasiswa dalam menyelarasakan contoh-contoh Bahasa lisan dan tulis mereka yang sangat kental dengan gaya komunikasi sehari-hari. Mahasiswa tidak memaksakan untuk menyerupai penutur asli tetapi ditunjukkan dalam rangkaian penyesuaian antara materi yang dipahami dengan titik keterbatasan yang dimiliki. Tips ini juga bermuara pada upaya sportif dan responsif dalam menemukan cara mengetahui materi ajar dengan pengetahuan yang dimililki mahasiswa dengan segala bentuk perbedaan individu melalui penyesuaian sajian materi dengan kemampuan dasar awal bahasa Arab.

Ketiga, terdapat tips alami yang juga ditunjukkan mahasiswa dalam belajar berbahasa Arab pada mata kuliah Bahasa Arab 1 dan Bahasa Arab 2 yaitu pada umumnya mahasiswa terlihat menyesuaikan perangkat pembelajaran, media, materi dan metode pilihannya dengan gaya yang menunjukkan kecenderungan penguasaan materi Bahasa Arab yang dipelajari sehingga mereka terlihat melakukan aktivitas belajar sesuai dengan kecenderungan gaya belajarnya masing-masing. Keterbatasan media yang dimiliki bisa ditaktisi dengan media yang tersedia, seperti yang terlihat pada lembar tugas Latihan Bahasa Arab. Meskipun instruksi penyelesaian tugas berbasis media (diketik) namun masih terdapat dokumen tugas belajar Bahasa Arab mahasiswa yang 
terkumpul dalam bentuk tulis tangan. Hal ini menunjukkan adanya tips untuk tetap memenuhi aktivitas pembelajaran Bahasa Arab.

Ragam tips tersebut berkorelasi dengan gaya belajar mahasiswa yang terangkum dalam kebiasaan merespon aktivitas belajar, baik dalam aktivitas berbahasa lisan maupun tulisan pada pembelajaran Bahasa Arab. Gaya belajar yang dimiliki oleh setiap mahasiswa berdampak pada tips yang diterapkan dalam mencapai tujuan belajar berbahasa Arab pada jenjang pendidikan tinggi. Kecenderungan yang dimiliki oleh mahasiswa dalam memanfaatkan tips tersebut berdasarkan kealamiaan kemampuan dasar Bahasa Arab mahasiswa, baik yang dominan merujuk pada keperibadian ekstrovert maupun pada keperibadian introvert. Perbedaan individu yang terjadi pada personaiti mahasiswa tersebut menjadi elaborasi konstruktif bagi keberhasilan penguasaan keterampilan Bahasa Arab.

\section{Penutup}

Perbedaan individu dalam pembelajaran bahasa Arab ditinjau dari dimensi gaya belajar mahasiswa pada Fakultas Tarbiyah dan Ilmu Keguruan IAIN Kendari menunjukkan bahwa dimensi gaya belajar mahasiswa lebih dominan dalam bentuk belajar berkelompok atau berbasis komunitas, meskipun masih ditemukan pula bentuk belajar individu. Kedua kecenderungan tersebut bersinergi dengan dimensi kepribadian mahasiswa dalam belajar bahasa Arab cenderung sesuai dengan kepribadian ekstrovert dan introvert. Sedangkan tips sukses dalam belajar Bahasa Arab dilakukan dengan cara, yaitu; pertama, mahasiswa memahami keterbatasan kemampuan dasar berbahasa Arab. Kedua, mahasiswa beradaptasi dengan segala bentuk perbedaan individu melalui penyesuaian sajian materi dengan kemampuan dasar awal bahasa Arab. Ketiga, mahasiswa menyesuaikan perangkat pembelajaran, media, materi dan metode sesuai dengan kecenderungan gaya belajarnya.

\section{DAFTAR PUSTAKA}

Amin Syamsuddin Makmun. (1999). Psikologi Kependidikan. Ramaja Rosda Karya.

Arsyad, A. (2009). Membangun Universitas Menuju Peradaban Islam Modern. Makassar: Alauddin Press.

Arsyad, A., \& Majid, N. (2010). Bahasa Arab dan Metode Pengajarannya: beberapa 
pokok pikiran. Pustaka Pelajar.

Baron, Renee; Wagele, E. (2015). The Power of Ennegram,. Serambi.

Brick, J. (2006). Academic Culture: A Student's Guide to Studying at University. Macquare University Press.

Bryman, A., \& Burgess, B. (2002). Analyzing qualitative data. Routledge.

Cook, V. (2008). Second Language Learning and Language Teaching The Fourt Edition. In Hodder Education. Hodder Education.

Crozier, W. R. (2013). Individual learners: Personality differences in education. Routledge.

Crystal, D. (2010). A Little Book of Language. Yale University Press.

Ellis, R. (1989). Understanding second language acquisition (Vol. 31). Oxford university press Oxford.

Gardner, H. (1993). Multiple Intellegence: The Theory in Practice. In Basic Books.

Hizbullah, N., \& Mardiah, Z. (2015). Masalah Pengajaran Bahasa Arab di Madrasah Aliyah di Jakarta. Jurnal Al-Azhar Indonesia Seri Humaniora, 2(3), 189-198.

http://kbbi. web. id. (2016). Kamus Besar Bahasa Indonesia Online.

Hurd, S. (2006). Individual learner differences and distance language learning: An overview. RTVU ELT Express, 12(4).

Ichsan. (2009). Pembelajaran Berbasis Individual. Jurnal Muqaddimah, 26(XV), 35.

Ihsan, M. (2017). Korelasi Sikap dengan Prestasi Belajar Bahasa Arab. Jurnal AlMutaaliyah: Jurnal Pendidikan Guru Madrasah Ibtidaiyah, 2(1), 1-24.

Kosim, N., Turmudi, I., Maryani, N., \& Hadi, A. (2020). Pembelajaran bahasa Arab melalui daring: Problematika, solusi dan harapan. Work From Home.

Lightbown, P. (n.d.). M./Nina SPADA (2006) How Language are Learned. Oxford: Oxford University Press.

Perdana, D. H. (2017). Strategi Penerjemahan Bahasa Arab yang Berterima dan Mudah Dipahami. Jurnal Bahasa Lingua Scientia, 9(1), 143-160.

Rachman, B. M. (2017). Pendidikan Karakter: Pendidikan Menghidupkan Nilai untuk Pesantren, Madrasah dan Sekolah. Jakarta: The Asia Foundation.

Zafar, S., \& Meenakshi, K. (2012). Individual learner differences and second language acquisition: a review. Journal of Language Teaching \& Research, 3(4).

Zagoto, M. M., Yarni, N., \& Dakhi, O. (2019). Perbedaan Individu dari Gaya Belajarnya Serta Implikasinya dalam Pembelajaran. Jurnal Review Pendidikan dan Pengajaran, 2(2), 259-265. 